\title{
Farm Women in American History: A Note on Sources Available in Washington, D. C.
}

\author{
KATHERINE JELLISON
}

SCHOLARS have largely ignored the history of American farm women. This neglect results not primarily from an absence of sources but from historians' failure to use available evidence. As historian Joan M. Jensen has noted in the introduction to her own excellent collection of farm women's primary documents, these women have "left far more records than their treatment by historians has led us to believe."1 The lives of twentieth-century farm women are especially well documented, owing to a number of developments in this century: the creation of large-scale government agencies to collect information about rural people, the evolution of documentary photography, and the development of voice-recording technology. Although evidence about the lives of farm women is held in archives and libraries throughout the nation, a significant portion of this material is located in the Washington, D.C., area.

The nation's capital has become a major center for scholars interested in the history of farm women. There are two reasons for this. First, the federal government has been responsible for gathering many of the existing documents about farm women, and much of the data generated by federal agencies is housed in government facilities in Washington. Second, individuals and organizations in the private sector have frequently donated materials dealing with farm women's history to the various well-known research centers and museums in the capital. As a

1. Joan M. Jensen, ed., With These Hands: Women Working on the Land (Old Westbury, NY, 1981), xviii.

THE ANNALS OF IOWA 51 (Fall 1991). CThe State Historical Society of Iowa, 1991. 
result, any scholar researching the history of American farm women may reasonably expect to spend some time in the District of Columbia.

Much of the material dealing with farm women's history is housed in the National Archives' main building in downtown Washington. A rich source of material for scholars researching the history of farm women is the archives' collection of materials that originated in the United States Department of Agriculture (USDA). Particularly useful are the correspondence records of the secretary of agriculture, which cover the years 1906 to 1970 and include 3,543 feet of correspondence. ${ }^{2}$ Among the letters included in this collection are a significant number of inquiries and comments from farm women. Women wrote to the secretary's office about their individual concerns as farm women. They also frequently wrote as spokespersons for their families and communities. Some women even wrote on behalf of male family members, reflecting the higher level of literacy among farm women than among farm men. Women were particularly prolific letter writers during times of economic crisis, perhaps because it was considered appropriate for women-but not for men-to plead for assistance. Women's management of the domestic arena also made them the logical family members to write letters describing their families' difficulty in procuring food, clothing, and domestic equipment. During the Great Depression, women wrote particularly vivid letters describing economic conditions on the farm and commenting on government relief programs. ${ }^{3}$

Depression-era farm women addressed their letters not only to the secretary of agriculture but to other persons who influenced USDA policies. Sensing that they could speak to the compassionate First Lady "woman to woman," farm women wrote perhaps their most informative and impassioned letters to Eleanor Roosevelt. A letter from Viola Bourret of rural

2. These documents are categorized as "General Correspondence of the Office of the Secretary" and are part of Record Group 16, Records of the Office of the Secretary of Agriculture. The letters in this collection are organized chronologically and by topic.

3. See Robert S. McElvaine's discussion of women's depression-era letters in The Great Depression: America, 1929-1941 (New York, 1984), 175. 
Stickney, South Dakota, was typical of those Eleanor Roosevelt received during the first year of her husband's administration. Commenting on the New Deal's plan to raise prices for major cash crops and large livestock-products that were generally men's responsibility-Bourret asked for similar aid to women's butter and egg business.

So far the men have had all the attention paid ... for reducing wheat acreage and ... for selling of pigs, but it is not getting us any where here.... in fact everything which we have to buy has gone up and the things we have to sell are going down in price: eggs, cream and chickens. This is the women's share of farm and small town money. ... So why not pay the women for their chickens and have them put them in cans or else put a price on them so that they will meet the price of things that we have to buy?... If the men cannot think of helping the women of the Country then surely we must intercede for ourselves. So Dear Lady, I am writing to you.... Will you intercede for the women here? ${ }^{4}$

Another source of farm women's correspondence to Eleanor Roosevelt is the National Archives' collection of letters dealing with the New Deal's subsistence homestead program. ${ }^{5}$ These documents are housed in the archives' facility at Suitland, Maryland, in suburban Washington. The women who wrote letters included in this collection were those at the bottom of the rural socioeconomic scale. Their letters are basically requests for information about how these women and their families might participate in the subsistence homestead program. The majority of the female letter writers were women whose families were displaced tenant farmers or sharecroppers or people who had lost their own farms. In most of these letters, women provided extensive life histories in their attempts to prove that they were "worthy" of federal assistance. These let-

4. Viola Bourret to Mrs. Franklin D. Roosevelt, 15 September 1933, Farm Relief File, (1) Misc. Farm Relief Plans (1933), General Correspondence of the Office of the Secretary (1906-1970), Records of the Office of the Secretary of Agriculture, Record Group 16, National Archives, Washington, DC.

5. These documents are categorized as "Correspondence with the General Public to Which Individual Replies were Made (1933-1935)" within the Records of the Division of Subsistence Homesteads, which are part of Record Group 96, Records of the Farmers Home Administration. 
ters thus provide excellent information about the era's poorest farm women.

Many of the nation's poor farm women, particularly poor women of color, were not literate, however, and thus provided no written documents about their own lives. Information about some of these "invisible" farm women may be found in the records of the Bureau of Agricultural Economics (BAE), housed in the archives' main building. ${ }^{6}$ The BAE was an economic research agency within the USDA, and this collection includes reports and papers written by social scientists who worked for the BAE. Although the BAE was not created until 1922, this collection also includes social science documents produced under predecessor agencies. Documents included in this collection thus cover the period from 1896 to 1953 , when the agency was abolished.

Many of the documents in the BAE collection are studies of farm women and farm families. One of the most extensive studies dealing with farm women was undertaken in the early 1920 s by USDA economist Emily F. Hoag. Hoag's study, "The Advantages of Farm Life: A Study by Correspondence and Interviews with Eight Thousand Farm Women," provides lengthy comments from farm women about their work and family lives and statistical information about their level of income and education, access to modern technology, and daily tasks. Although Hoag's study is problematic-for example, her methodology favored the inclusion of middle- and upper-class farm women-it provides a wealth of information about gender roles and women's work on the family farm.

During the New Deal era, BAE researchers produced more studies dealing with the experiences and conditions of the nation's poorer farm families and communities. The BAE greatly expanded during Franklin Roosevelt's presidency and became chiefly concerned with the conditions of small farmers and farm tenants. ${ }^{7}$ Under the direction of eminent rural sociologist Carl C. Taylor, BAE researchers at this time produced

6. The Records of the Bureau of Agricultural Economics are in the Archives' Record Group 83.

7. See Richard S. Kirkendall's discussion of the BAE in Social Scientists and Farm Politics in the Age of Roosevelt (Columbia, MO, 1966). 


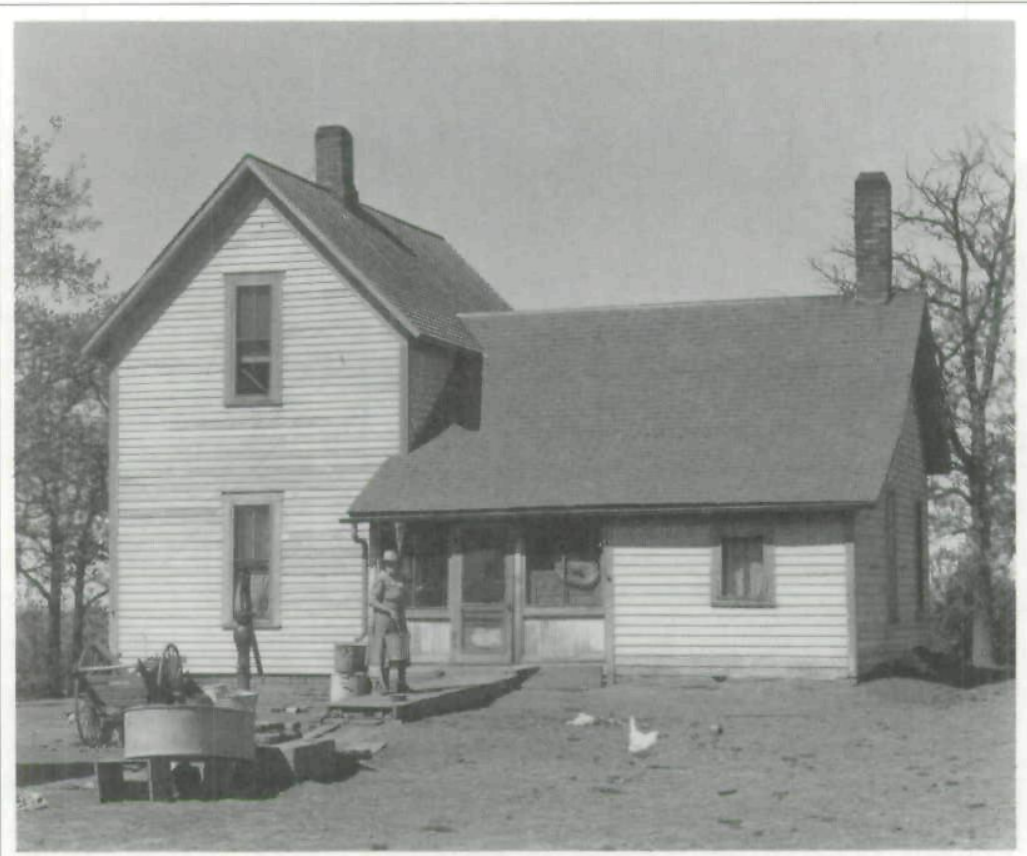

Fig. 1. Shelby County, Iowa, May 1941. Photograph by Irving Rusinow, courtesy of BAE Collection, National Archives,

Washington, D.C.

several pathbreaking studies, including a series of investigations designed to study the economic, cultural, and social stability of six rural communities across the United States. These six studies, each published in 1942 under the title Culture of a Contemporary Rural Community, were among the first works to offer significant discussions of rural gender roles; each of the studies gave women's activities considerable attention. ${ }^{8}$ These classic works in rural sociology are available in government document libraries throughout the nation, but the original photographs made in conjunction with the series are only available through the Still Pictures Branch of the National Archives, housed in the archives' main building.

The photographs that illustrate the 1942 studies show farm women engaged in their daily tasks and are particularly

8. The six communities studied were Irwin, Iowa; Sublette, Kansas; El Cerrito, New Mexico; the Old Order Amish of Lancaster County, Pennsylvania; Landaff, New Hampshire; and Harmony, Georgia. 
useful in showing the types of equipment that women employed to perform their agricultural and household chores. These photographs also provide invaluable information about farm women's dress, housing, and recreational activities in these six economically and ethnically diverse farm communities (see fig. 1). In addition to the BAE photographs, the Still Pictures Branch holds hundreds of USDA photographs of farm women from the late nineteenth century through the postWorld War II era. The best of these photographs show farm women at work: harvesting crops, canning vegetables, purchasing goods at the general store. Such photographs tell much about the daily experiences of America's farm women. ${ }^{9}$

The most famous Washington-based collection of photographs of farm women, however, is the set of Farm Security Administration (FSA) photographs housed in the Prints and Photographs Division of the Library of Congress. Once again, a New Deal agency, the FSA, provided photographic images of the nation's poorest farm people, people whose lives otherwise might have remained in obscurity. The talented photographers who worked for the FSA made 270,000 negatives in their quest to document the experiences of America's tenant farmers, sharecroppers, and migrant farm workers. Among their bestknown subjects were rural women, including Dorothea Lange's famous Migrant Mother (see illustration accompanying the following review essay). ${ }^{10}$

In addition to providing viewers with dramatic images of America's impoverished farm women, the FSA photographs also provide information about the material conditions of the women in those photographs. For example, Russell Lee's 1938 photograph of an African-American woman at her back porch washboard shows a woman using the only laundry equipment available to most residents of New Madrid County, Missouri (see fig. 2). Lee's series of photographs of the Schoenfeldt fam-

9. The BAE photographs are in the Archives' Record Group 83-G; the other USDA photographs are found in Record Group 16-G.

10. For a good critical discussion of the FSA photographs and other government-sponsored photography of the era, see the essays by Pete Daniel, Merry A. Foresta, Maren Stange, and Sally Stein in Official Images: New Deal Photography (Washington, DC, 1987). Many of the FSA photographs are also reproduced in this book. 


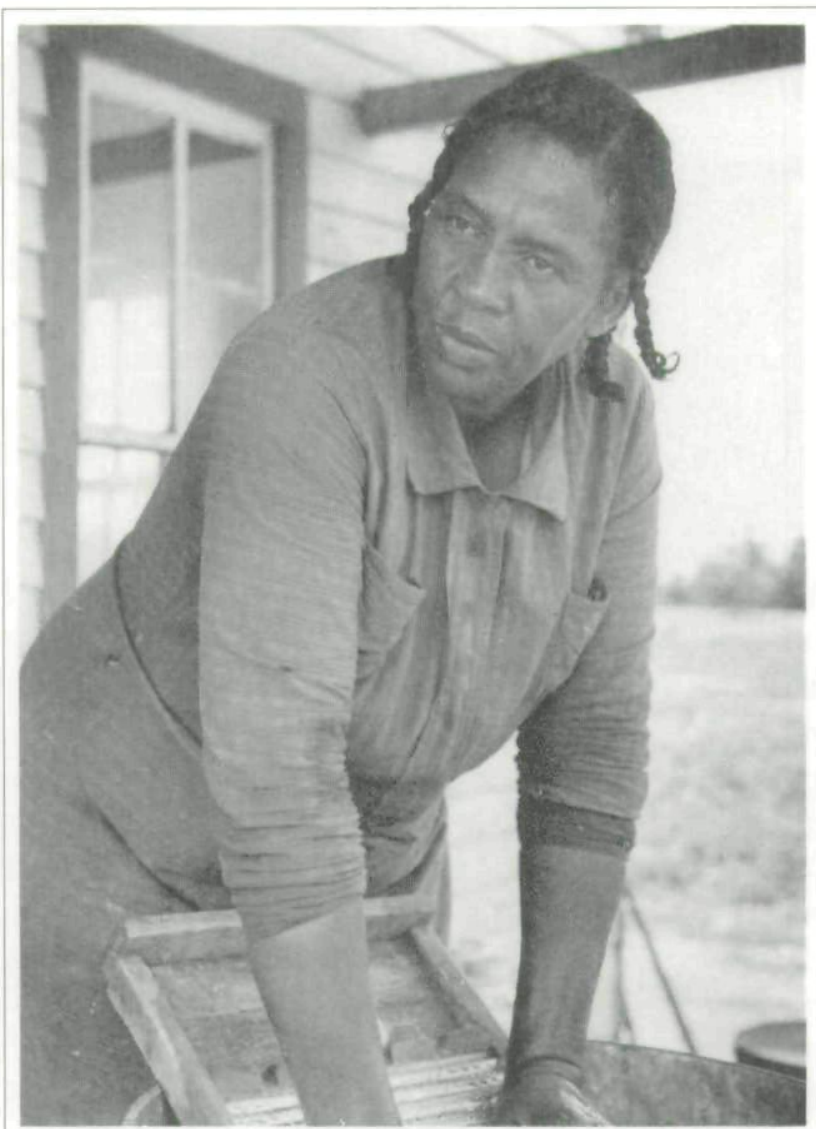

Fig. 2. New Madrid County, Missouri, May 1938. Photograph by Russell Lee, courtesy of FSA Collection, Library of Congress, Washington, D.C.

ily of Sheridan County, Kansas, shows people who, as late as 1939, were still living in a sod house. The family matriarch, however, had availed herself of one piece of modern technology. In his portrait of the home's interior, Lee reveals Mr. and Mrs. Schoenfeldt standing in front of a freshly white-washed wall, covered with Catholic iconography and other keepsakes, and Mrs. Schoenfeldt-grease-stained apron, disheveled hair, and all-is posing with her most prized possession, "her pressure cooker of which she is very proud" (see fig. 3).

Another type of evidence that provides information about those farm women who did not leave behind their own written 


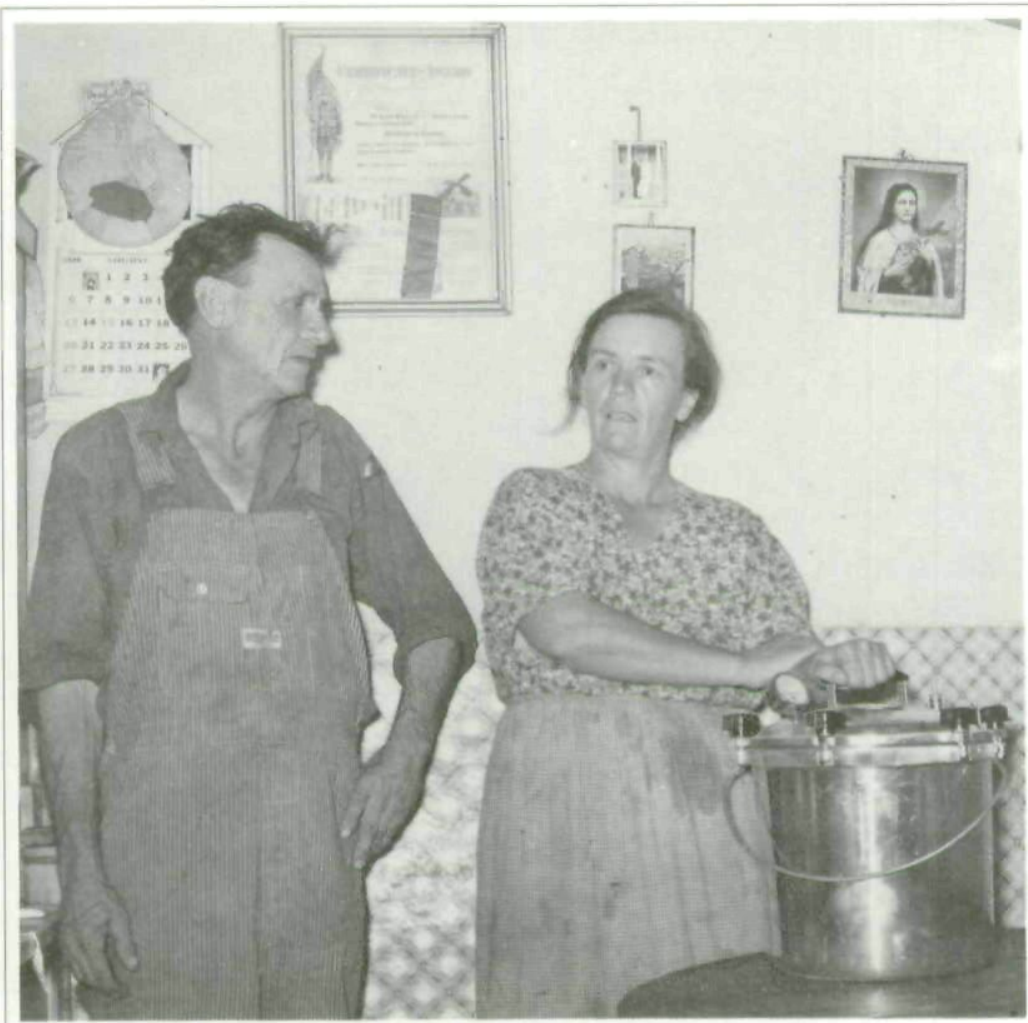

Fig. 3. Sheridan County, Kansas, August 1939. Photograph by Russell Lee, courtesy of FSA Collection, Library of Congress.

accounts is oral history. A particularly useful oral history collection available in the Washington area is the Oral History of Southern Agriculture project held by the Division of Agriculture and Natural Resources at the Smithsonian Institution's National Museum of American History. This collection includes a significant number of transcribed interviews with white and nonwhite women who lived and worked in the rural South and whose descriptions of their experiences provide information that is unavailable in traditional written sources. The Division of Agriculture and Natural Resources also has on file information about numerous other oral history collections that include the testimony of rural women and are located in archives around the country. ${ }^{11}$

11. For further discussion of this collection, see Nancy Grey Osterud and Lu 
For historians interested in the material culture of America's farm women, the Smithsonian Institution has presented several recent exhibits that include the everyday objects of America's women of the land. The "After the Revolution" exhibit at the National Museum of American History includes. the tools and possessions of rural Euro-American, AfricanAmerican, and Native American women who lived in the Early Republic. The "Field to Factory" exhibit, also in the Museum of American History, is an examination of the experiences of southern blacks who migrated to the urban North in the twentieth century, and it does a good job of showing the material conditions of these rural black women and their families. Another recent exhibit dealing with the work and daily experiences of rural women featured quilts made by southern slave women and was on view at the Smithsonian's Renwick Gallery. Such exhibits not only allow researchers a pleasant diversion from file boxes and photocopy machines but may also provide greater insight into the lives of women who left no written records of their lives but who left behind the implements and objects they created and used.

For anyone interested in seriously investigating the history of rural women in America, research in the Washington area is a "must." In order to make the best use of the rich sources available there, however, one must make some preparations in advance. The following are suggestions for persons interested in conducting research on farm women at various of the Washington area facilities:

National Archives: Persons interested in doing research at the National Archives must first obtain a research card and consult with a member of the archives staff. A free shuttle service between the downtown building and the facility in Suitland, Maryland, is available to persons interested in using material at both buildings. For additional information about the

Ann Jones, "'If I Must Say So Myself': Oral Histories of Rural Women," Oral History Review 17 (Fall 1989), 1-23. This review essay, which introduces a special issue of the Oral History Review devoted entirely to the subject of rural women and oral history, presents an excellent overview of available collections and major works on the history of rural women that have made use of oral history material. 
archives' facilities, holdings, and regulations, contact the Reference Services Branch at (202) 501-5400.

Library of Congress: People interested in using the FSA photographs will find them easily accessible in the Library of Congress's Madison Building, which houses the Library's Prints and Photographs Division. No special arrangements are necessary to use these facilities and view the photographs. For further information, contact the division's reference staff at (202) 707-6394.

National Museum of American History: Researchers interested in using the Oral History of Southern Agriculture material or in obtaining information about other oral history collections may contact staff members of the Division of Agriculture and Natural Resources at (202) 357-2095. 
Copyright of Annals of Iowa is the property of State of Iowa, by \& through the State Historical Society of Iowa and its content may not be copied or emailed to multiple sites or posted to a listserv without the copyright holder's express written permission. However, users may print, download, or email articles for individual use. 